\title{
Agricultural Inputs for Organic Agriculture
}

\author{
Soytong, K., Song, J. J. and Tongon, R. \\ Faculty of Agricultural Technology, King Mongkut's Institute of Technology Ladkrabang (KMITL), Bangkok, Thailand; \\ Association of Agricultural Technology in Southeast Asia (AATSEA) \\ Corresponding author: E-mail address: ajkasem@gmail.com
}

\begin{abstract}
Sustainable development concerns on saving energy and the environmental friendly reservation and to serve healthy and safety food. The history of agricultural production using chemical fertilizers, pesticides and other synthetic chemicals for crop and animal production is to increase yield become harzardous to human being and living things in our environments. We have proposed the modern organic agriculture model to serve the sustainable development goal (SDGs) that possible be a new combination practical technology for organic agriculture. The research investigation is still needed to find more bioproducts and natural producrts to contribute knowledge for non-agrochemical production (NAP) transition period to organic agricultural production. The demonstration organic model is proposed which consisted of organic crop production, organic animal production, understanding bioproducts and natural products as agricultural inputs, seed production, food preservation, animal feed, organically certification by trusted agencies, organic markets and practical training. The certified agricultural inputs for organic agriculture is needed for acceptable used eg. biological fertilizers (compost) and biofungicides, bioinsecticides, bioherbicides, and biological nutrition. The other combination techniques are proposed as cultural practice, crop rotation, inter-cropping, organic amendment, biochar technology. The net house, greenhouse in closed or semi-closed system to control temperature and relative humidity are also concerned. The herbs or medicinal plants, and natural wood vineagar to eliminate plant pathogens and insects are introduced. The light and yellow traps, natural pheromones, natural sulfur, white oil, repellent plants, neem-oil etc. are recommended. We have been conducted to investigate the bioproducts sine 1989 and those bioproducts are gradually contributed to farmers. Our research successfully findings are contributed as bio-remediation and bio-decomposer for revitalizing the soil to get rid of the heavy metals residue in the cultivated soil and make compost, the different formulations of organic-inorganic biological fertilizers with high nitrogen, phosphorous, potassium, calcium and magnesium etc. and biological nutrients for plant growth to be used instead of chemical fertilizers. Chaetomium myco-fungicide for broad spectrum plant disease control and the biodegradation natural product fine particles acts as natural elicitor for plant immunity. We have promoted to do organic agricultural production and certification until delivery to the markets.
\end{abstract}

\section{Keywords: Organic agriculture, Sustainable development, Agricultural inputs}

\section{INTRODUCTION}

The sustainable agriculture producing healthy food towards organic agriculture is increasingly interested. "Sustainable development" defines as an energy saving and environmental reservation for safety food. The real practical without application of toxic agrochemicals lead to non-toxic agriculture product must be proved. The synthetic agrochemicals are released to the farmers in the mid-19th century that was cheap and rapid response to plants, and chemical pesticides expected to occur for pest eradication as agricultural input in the 1940s. Agriculture in history has been concerned in application of synthetic chemicals eg. chemical fertilizers, chemical herbicides, chemical insecticides, chemical fungicides and the other synthetic chemical like plant growth regulators for animal and crop production, thereafter the side effects of unbalanced agroecosystem and environmental pollutions as well as cultivated soil become compact, low acidity, low organic matter and the beneficial living things are limited in the soil and surrounding environment. Human being are faced those toxic synthetic chemicals in agriculture by toxic residues leading to get sick and short life. Organic agriculture model for sustainable development is established to contribute the research findings of biological products as agricultural inputs for non-agrochemical production (NAP). Organic agriculture (OA) has come out with many definitions and explanations that still unclear. Some defines as to realize agroecosystem and reserve natural energy rather than 
external agricultural inputs, practical without agrochemicals from generation to generation for thousands of years. Other defines as the management system to enhance and stimulate the agroecosystem including biological diversity. This may be achieved by using agronomic, biological, and mechanical methods. The definition of our experienced in organic agriculture would be defined as strictly non-agrochemical application (NAP) for crop and animal production. The inputs for organic agricultural production would be certified by the trusted agencies leading to the bioproduct research for organic agriculture be acceptable applied in organic farms eg. biofertilizers and biopesticides. Other cultural practice in agriculture are integrated methods for organic production like crop rotation, compost production, herbs or medicinal plants for insect and disease control. The natural inorganic substances products without synthetic chemical in process to be finished products, non-genetically modified organism etc. It concerns in environmental reservation, ecological balance and sustainable development in agro-ecosystem. It is to manage and maintain soil fertility and prevent diseases and insect pests without synthetic agrochemical application.

\section{DEFINITION}

Organic agriculture may define as the management system to stimulate the agroecosystem to maintain biological diversity which accomplished by agronomic, biological, and mechanical methods, with opposite to synthetic agrochemicals [1]. Animal and crop production have needed agrochemicals since in the mid-19th century. The naturally organic agriculture had been done before the agrochemicals appeared due to many biotic and abiotic factors which involve to decrease yields. The scientists had tried to solve those problems by chemical ways for the last 100 years. Our experienced in organic agriculture define non-synthetic agrochemicals using for agricultural production, and processing until deliver to the consumers. Then, agricultural products would be safely to consume without any residue of toxic agrochemicals. Organic agriculture concerns are all agricultural production systems to encourage environmental friendly system that concerns in soil fertility as a tool to accomplish the production.

Organic production supports the management system to promote agro-ecosystem and biodiversity. Organic agriculture is started in the early 1900s with work of Englishman Sir Albiert Haward, who initiated "organic growing method" in India. Thereafter, the organic mean is introduced by Rudolf Steiner and Ehrinfried Pfieffert who proposed the biodynamic methods which concerns with the living organisms and needs to be replenished and revitalized in the earth [2]. OA do not allow the growers to use the synthetic pesticides and chemical fertilizers. The growers must be integrated the cultural practices, crop rotation, intercropping etc. as environmentally friendly inputs.

\subsection{AATSEA Organic Model}

Organic agricultural production model has proposed as demostration organic farm including crop and animal production, agricultural inputs for organic production, farm management, organic certified, marketing and processing, extension and training, research and development (Figure 1). AATSEA organic farm is established in 2017 by commercial scale production. It is a pilot model for organic crop and animal production.

ORGANIC AGRICULTURE MODEL

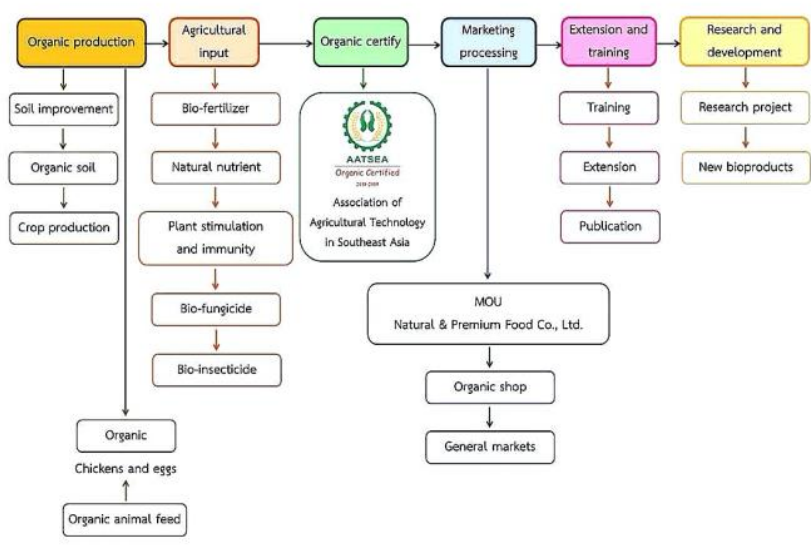

Figure 1. Organic agriculture model

\subsection{Agricultural Inputs}

Agricultural inputs are importantly needed for organic agriculture production, especially biological fertilizers, biological nutrients, biological insecticides, biological fungicides and biological herbicides together with other cultural practices and conventional methods. Biopesticides are necessary to prove by scientific research on biological products for plant disease control, insect protection, growth stimulants and different kinds of biological fertilizers to replace the chemical ones. It is to maintain the quality and quantity of organic production.

There are many scientists has conducted on biological pesticides as agricultural inputs for organic agriculture. The authors are one of researcher group to investigate and find out the agricultural inputs for organic 
agriculture which are released to the organic growers as biofertilizers, Chaetomium biofungicide, microbial elicitor for plant immunity, bio-insecticide and bio-nutrients etc.[3]. The agricultural inputs must be certified as agricultural inputs by organic certified agencies for acceptable used farms. Other biological techniques are included cultural practice, crop rotation, compost production, medicinal plants or herbs for diseases and insect control (sulfur, pheromone, insect trap. white oil etc.), green manure, composted manure, bone meal, crop rotation, inter-cropping , biological control, insect predators, natural substances etc. The natural inorganic substances products without synthetic chemical in process to be finished products, and nongenetically modified organism, [4] including wood vinegar, white oil, biochar and organic seeds.

Biological fertilizers for organic crop production are performed in different kinds of biofertilizers. Our research findings are proposed as follows:- Organic-biofertitlizer contains high potential microorganism producing enzymes of cellulose, hemicellulase, ligninase and protease etc. as follows:- Achaetomium sp., Trichoderma sp., Eurotium sp., Emericella sp., Rhodopseudomonas sp. to degrade organic and inorganic substances which passed fermentation to get more available nutrients to increase soil fertility and promote for plant growth. The organic biofertilizer standard would meet over $20 \%$ organic matter, $\mathrm{pH}$ 6.5-6.8, contains major ( $\mathrm{N}, \mathrm{P}, \mathrm{K}, \mathrm{Ca}, \mathrm{S}, \mathrm{Mg}$ ) and minor elements $(\mathrm{Cu}, \mathrm{B}, \mathrm{Mo}$, $\mathrm{Fe}, \mathrm{Zn}, \mathrm{Cl}, \mathrm{Mn}$ ) for plant growth. It can apply for land preparation to cultivate rice or apply at seedling stage at for $50-100 \mathrm{~kg} / \mathrm{acre}$. Fruit trees are introduced to apply after harvesting and pruning at the rate of $2-5 \mathrm{~kg} /$ tree. Vegetables and other plants are suggested to apply in early stage of plant growth at the rate of 100-150 kg/acre. Moreover, high phosphorous biofertilizer can be applied the specific isolates of fungi, Aspergillus niger, Penicillium sp., Chaetomium lucknowense, Actinomycetes to degrade rock phosphate, animals bond etc. to get more available phosphorus (P) for induce flower buds etc. High potassium biofertilizer is the sterilized ground potassium feldspar or as was mixed with the potent selected fungi, Aspergillus sp, Penicillium sp., Chaetomium sp., Actinomycetes for degradation to get more available potassium (K). The potassium biofertilizer can be used to high crop yield $[5,6$, $7,8,9,10]$. Bio-decomposer is the potent microorganisms which consisted of Achaetomium sp., Aspergillus oryzae, Emericella nidulans, Eurotium chevaleri, Penicillium multicolor, Trichoderma harzianum, Trichoderma hamatum. It uses to mix in plant and animal debris for fermentation process to be compost or organic fertilizer. The composition to make compost are as follows:- biodecomposer $250 \mathrm{~g}$ per plant and animal debris $1,000 \mathrm{~kg}$ with $10 \mathrm{~kg}$ lime. For degrading rice straws in paddy, it can apply $250 \mathrm{~g}$ bio-decomposer per 1,600 $\mathrm{m} 2$ before plough to prepare paddy field-soil prior to transplanting for 7-15 days
$[11,12]$. Nutri-crop has contributed as naturally nutrient supplement for plant stimulating growth. This biological product is contained the naturally plant nutrients to promote plant growth. It consisted of natural amino acids $22 \%$, humic acid $10 \%$, total nitrogen $(\mathrm{N}) 6.8 \%$ and potassium oxide (K2O) $1.68 \%$ in combination with two effective strains of photosynthesizing bacteria, Rhodopseudomonas spp. It helps to fix nitrite to be nitrate, and sulfide to be sulfate for the growth of plants. Organic cultivated plants are recommended to apply at the concentration of $50 \mathrm{cc} / 20$ $\mathrm{L}$ of water.

Nutri-food is one of the research finding for increasing yield is developed by mixing the naturally potassium humate with $T$. harzianum and two strains of effective photosynthesizing bacteria, Rhodopseudomonas spp. in powder formulation. It contained the natural plant nutrients to stimulate plant growth and increase yield. The rate of application is recommended to apply at $50 \mathrm{~g} / 20 \mathrm{~L}$ of water and spray to plant and under canopy.

Chaetomium biofungicide is a unique bioproducts for disease control. Our research investigation on biological control of phytopathogens have been started since 1996 [13]. Chaetomium sp. recorded to be effectively against the blast incidence of rice pathogen caused by Pyricularia oryzae in the Philippines. It has been developed as a broad spectrum biological fungicides to control plant disease [14]. Chaetomium biofungicide and biofertlizer is patented and registered in Thailand, China, Cambodia, Laos and Vietnam [15]. It consisted of 22 synergistic isolates of Ch. globosum and Ch. cupreum in combination into one formulation either powder or liquid forms. Chaetomium biological fungicide is an unique bioproduct used to control many diseases of plants in many countries. Ch. cupreum and Ch. globosum are recorded to reduce the corn leaf spot caused by Curvularia lunata, rice blast incidence caused by Pyricularia oryzae, rice sheath blight caused by Rhizoctonia oryzae and wilt of tomato caused by Fusarium oxysporum f.sp. lycopersici [16, 17]. The bioactive pure compound from Ch. globosum KMITL-No802 produced chaetomanone, ergosterol, ergosteryl palmitate, chrysophanol, chaetoglobosin $\mathrm{C}$, alternariol monomethyl ether, echinuline and isochaetoglobosin D. Withthis, chaetomanone and echinulin expressed antifungal biological activity against Mycobacterium tuberculosis causing tuberculosis in human[18]. These bioactive compounds are feasible acted as control mechanism against plant pathogens. There were numerous reports indicating that Ch. globosum gave a good control seedling blight of wheat (Helminthosporium victoriae) [19]. The ascospores of Ch. globosum reported to control Venturia inequalis causing the apple scab[20]. Ch. globosum and Ch. cupreum are completely controlled the root rot of durian, citrus, black pepper, decreased damping off disease of sugar beet [21], rice blast incidence (Magnaporthe oryzae), and root rot of 
durian (Phytophthora/Pythium). The fine powder and pelletized formulations of Ketomium ${ }^{\circledR}$, as a broad spectrum mycofungicide has been registered as a biological biofertilizer for degrading organic matter and to induce plant immunity and stimulate plant growth It was recorded that Ketomium-mycofungicide from Thailand was most efficient to control raspberry spur blight (Didymella applanate) and reduced potato disease (Rhizoctonia solani) and increasing potato yield [22]. After 2 years in storage, Ketomium biofungicide from Thailand was still capable to inhibit of the growth of plant pathogens in higher doses [21]. The biological fungicide formulated from 22 potent isolates of Ch. cupreum and Ch. globosum resulted to control =root rot of durian caused by $P$. palmivora in the fields which Chaetomium can be reduced the pathogen inoculum of Phytophthora after applying to soils planted to Durian var Monthong in Thailand [23]. Chaetomium biological fungicide is recorded to control citrus root rot caused by Phytophthora parasitica in the fields [24]. Chaetomium biological fungicide is applied to Fusariuminfested soils where tomatoes were grown and it had success fully controlled the pathogen inoculum and reduced disease infection. It has been successfully controlled as Fusariumsuppressive soils and the tomato plants treated with Chaetomium bio powder compared to Pentachloronitrobenzen (PCNB) resulted to be completely controlled the damage by $F$. oxysporum f. sp. lycopersici. $P$. palmivora causing rot of black pepper which significantly lower disease incidence [4]. Moreover, the tested Chaetomium biological product has been proved to control several diseases in the fields to control root rot of durian [23] black paper [25] and tangerine [26]. Chaetomium is a unique board spectrum biofungicide is registered in Thailand, China, Laos, Vietnam, Cambodia, and BioAgriCert, International Federation of Organic Agriculture Movements(IFOAM). The countries contributed and tested Chaetomium biofungicide for disease control in Philippines, Malaysia, Singapore, South Korea, Taiwan, China, Vietnam, Laos, Myanmar, Bangladesh, Indonesia, Cambodia, Netherlands, Sweden, Russia, Georgia, Belgium, Argentina, Brazil, Costa Rica, South Africa, Iran, Egypt and Finland. At present, it is registered in Cambodia, Laos, Vietnam and being registered in China and BioAgriCert, IFOAM. Biodegardable nanoelicitors constructed from active metabolites from Chaetomium species are the new unique science for plant immunity which have been contributed in Thailand, Finland, Indonesia, India, Laos, Cambodia, Myanmar, Vietnam and China. Our experiences of research in this area of specialization will be continued to find more biological products for sustainable agriculture. Interestingly, Chaetomuim spp. are reported to be antagonized plant parasitic nematode and insects. The diverse research was on Chaetomium which carried out for agricultural purposes.
Some researchers demonstrated the endophytic Chaetomium that exhibited antibiosis against nematodes e.g. Meloidogyne incognita (root-knot nematode), inhibited hatching eggs of Heterodera glycines (soybean cyst nematode) and Globodera pallida (cyst nematode). Some species of Chaetomium recorded to be controlled insects e.g. cotton aphids (Aphis gossypii) and beet armyworms (Spodoptera exigua). It is reported the metabolites from $\mathrm{Ch}$. globosum reduced the hatching eggs and disturbed mobility of Meloidogyne incognita (root-knot nematode) and inhibited the hatching eggs of Heterodera glycines (soybean cyst nematode) [27]. Aavipin is an active metabolite from Ch. globosum TAMU 520 reported to be an active agent to control root knot nematode causing problem in Muskmelon (Cucumis melo). Ch. globosum confirmed to control root-knot nematode (Meloidogyne incognita) which decreased the female reproduction. Ch. globosum proved to be nematicidal effect and its metabolite is patented in China as a patent No. CN102925369A in 2012 by a group of Chinese Scientists which claimed that $C h$. globosum NK106 (CGMCC6716). Chaetoglobosin A prevents the plant parasitic nematode due to high toxicity and nematicidal activity against the juvenile stage of Meloidogyne incognita. Chaetoglobosin A at $300 \mathrm{mg} / \mathrm{mL}$ showed the lethality is about $90.2 \%$, and decreased the nematode eggs by $63 \%$. In 2016, Hu et al. stated that chaetoglobosin A, the secondary metabolites produced by Ch. globosum NK102 expressed the nematicidal activity M. incognita. Chaetomium globosum NK102 repelled secondstage juveniles. Chaetoglobosin A showed strongly adversed effects in secondary stage mortality of nematode with $99.8 \%$ at $300 \mu \mathrm{g} / \mathrm{mL}(\mathrm{LC} 50=77.0 \mu \mathrm{g} / \mathrm{mL})$ at $72 \mathrm{~h}$. Chaetoglobosin A and filtrates from Ch. globosum NK102 had no affected on egg hatch until $72 \mathrm{~h}$. The filtrate treatments inhibited the penetration of second-stage juveniles at $12.5 \%$ dilution treatment. Chaetoglobosin A also inhibited the penetration of secondary stage and reduced the number of nematode eggs [28]. Moreover, $C h$. globosum is reported to be a fungal parasite which isolated from egg of Globodera pallida (cyst nematode) in USA. It showed the greatest reduction of the infection by G. pallida in potato of $76 \%$ [29]. The endophytic Ch. globosum YSC5 showed nematicidal metabolites activities against the second stage juveniles of Meloidogyne javanica. Chaetoglobosin A, Chaetoglobosin B and flavipin strongly inhibited (91.6, 83.8 and $87.4 \%$, respectively) on mortality of the second stage juveniles at $200 \mu \mathrm{g} / \mathrm{mL}$ with LC50 values of $88.4,107.7$ and $99.2 \mu \mathrm{g} / \mathrm{mL}$ after $72 \mathrm{~h}$, respectively, 3-methoxyepicoccone and 4,5,6-trihydroxy7-methylphthalide moderately inhibited at 78.0 and $75.5 \%$, respectively with LC50 values of 124.0 and $131.6 \mu \mathrm{g} / \mathrm{mL}$, respectively. The promising metabolites of Chaetoglobosin A, chaetoglobosin B significantly reduced nematode reproduction in pot experiment [30]. Chaetomium as insect 
control was recorded by who explained the above ground of cotton plants, endophytic $C h$. globosum was negatively affected the fecundity of cotton aphids (Aphis gossypii) and beet armyworms (Spodoptera exigua). The beet army worm larvae were smaller head capsule after treated Chaetomiumcolonized plants. Bot-F is developed biological metabolites released from specific isolates of Chaetomium. The fungal active compounds expressed activity against plant pathogens, Phytophthora sp. (root rot of plants) and Colletotrichum gloeosporioides (anthracnose). Chaetomium cochliodes VTh 01 and Ch. cochliodes CTh 05 were proved to suppress Fusarium oxysporum f sp lycopersici (tomato wilt). Moreover, Chaetominedione is found to be a new tyrosine kinase inhibitor isolated from the algicolous marine fungus Chaetomium sp. [31]. The fungal metabolites from Chaetomium antagonistic fungi to control plant pathogens have been explained to be one of the control mechanisms that imply antiobiosis. The research finding noted that the bioactive substances extracted from $C h$. globosum CG can be inhibited sporulation of plant pathogens e.g. Colletotrichum gloeosporioides (citrus anthracnose), Fusarium oxysporum f. sp. lycopersici (tomato wilt), Phytophthora parasitica (root rot of citrus) and $P$. palmivora (root rot of black pepper). Chaetomium globosum is recorded to produce chaetoglobosin C to inhibit the growth of plant pathogens such as Colletotrichum gloeosporioides, C. dematium, F. oxysporum, P.palmivora, $P$. parasitica, $P$. cactorum, $P$. oryzae, Rhizoctonia solani and Sclerotium rolfsii and chaetoviridins A inhibited the growth of Magnaporthe grisea (Pyricularia oryzae), Pythium ultimum [32]. Chaetomium cupreum noted to produce rotiorinol that inhibited the pathogens [33]. Chaetomium globosum reported to produce chaetoglobosin $\mathrm{C}$ that inhibited the pathogens e.g. P. palmivora etc. The application rate is recommended by spray to plants at the concentration of $50 \mathrm{cc} / 20$ litres of water at 7-10 days for infected plants, and 15-20 days for protection. Biodegrable nano-particles for plant immunity is constructed from active natural products of different species of Chaetomium for immunity. The biodegradable nanoparticles from natural products of active metabolites of Chaetomium spp. are further investigated and discovered as a new scientific investigation, namely microbial degradable nano-elicitors for inducing immunity in plants by the authors. In recently years, the scientists are actively investigated the organic nanomaterials of different kinds of nanoparticles possessing biological properties [34,35]. The nanotechnology for agriculture is interested in various areas. [36]. Plant disease control is to decrease or eliminate the non-target effects either abiotic or biotic factors. Nano-sciences have become a new method to restructure the materials at atomic level. Molecular nanotechnology can be constructed the organic materials into defined structures and atom by atom [37]. The natural products from Chaetomium species are proved for antifungal strategy against several plant pathogens. The alternative disease control is to safe, effective, and environmentally friendly methods to control plant pathogen is highly needed. The construction and characterization of copolymer nanoparticles loaded with bioactive compounds from Chaetomium species have been searched rather than toxic chemical pesticides. The natural products from fungal active metabolites from Chaetomium spp. which constructed to be fine particles at molecular level as degradable nanoparticles used to control plant disease and induce plant immunity were investigated by electron spinning. Biological control research unit, Faculty of Agricultural Technology, King Mongkut's Institute of Technology (KMITL), Bangkok, Thailand has been gradually developed the research on biological control technology for years. Degradable nano-CGH, nano-CGE, and nano-CGM constructed from Ch. globosum KMITLN0805 actively inhibited Curvularia lunata causing leaf spot disease of rice var. Sen Pidoa in Cambodia. The effective dose of $50 \%\left(\mathrm{ED}_{50}\right)$ of degradable nano-CGH, nano-CGE, and nano-CGM were $1.2,1.1$, and $1.9 \mu \mathrm{g} / \mathrm{mL}$, respectively at very low concentration to inhibit leaf spot pathogen of rice. These biodegradable nanoparticles actively forwarded to the pathogen cells to become disruption and distortion, those pathogen inocula lost pathogenicity according to preliminary Koch's postulate test. The nano-CGH, nano-CGE, and nano-CGM inhibited spore production by $92 \%, 93 \%$, and $84 \%$, respectively and resulted antifungal activity against $C$. lunata with $\mathrm{ED}_{50}$ values of $1.2,1.1$, and $1.9 \mu \mathrm{g} / \mathrm{mL}$, respectively. The applications of degradable nano-CGH, nano-CGE, and nano-CGM to inoculated $C$. lunata on rice seedlings var Sen Pidoa gave a good disease in pot experiments. Degradable nano-CGH and nano-CGM gave higher disease reduction of rice leaf spot caused by $C$. lunata $(61 \%)$ than nano-CGE (53\%). These biodegradable nanoparticles significantly increased the height and number of tillers of the rice plants at 60 days after treatment

Chaetomium cochliodes isolate CTh05 expressed actively against the rice blast pathogen, Magnaporthe oryzae isolate PO1 on rice var RD57 in Thailand. The rice blast reduced infection (59\%) after applying nano-CCoM at $7 \mu \mathrm{g} / \mathrm{mL}$, followed by nanoCCoE and nanoCCoH which reduced the blast infection of $57 \%$ and $50 \%$ respectively. But tricyclazole fungicide reduced blast infection of $55 \%$ in 30 days [38]. Further reported on antifungal efficacy of microbial nano-particles constructed from $C h$. elatum, $C h$. lucknowense and Ch. brasiliense against rice blast pathogen in rice var. PSL 2 in Thailand. Nano particles of Ch. elatum (nano-CEE, nano-CEM and nano-CEH) inhibited sporulation of $M$. oryzae which the $\mathrm{ED}_{50}$ values of 7,8 and $16 \mu \mathrm{g} / \mathrm{mL}$. respectively. The nano-CBH, nano-CBE and nano-CBM constructed from $C h$. brasiliense suppressed sporulation the blast pathogen which the $\mathrm{ED}_{50}$ values of 6 , 
9 and $13 \mu \mathrm{g} / \mathrm{mL}$, respectively. Nano-particles from $\mathrm{Ch}$. lucknowense (Nano-CLM, nano-CLE and nano-CLH) inhibited sporulation of rice blast pathogen which the $\mathrm{ED}_{50}$ values of 5, 7 and $10 \mu \mathrm{g} / \mathrm{mL}$, respectively. Interestingly, all tested nano-particles derived from Chaetomium caused pathogenicity lost of rice blast pathogen due to the broken of pathogen cells. The treated rice leaves with nano-CBH from Ch. brasiliense showed the $\mathrm{Rf}$ values of 0.05 and 0.28 which defined to produce Sakuranertin and Oryzalexin B as phytoalexin against blast disease [39]. Degradable nano$\mathrm{CGH}$ and nano-CGM gave higher disease reduction of rice leaf spot caused by C. lunata $(61 \%)$ than nano-CGE (53 $\%)$. These nanoparticles significantly increased the height and number of tillers of the rice plants at 60 days after treatment.

These active natural products from different strains of Chaetomium are further developed to be biodegradable nanoparticles from active metabolites as a new discovery of scientific investigation which used to induce plant immunity, namely microbial degradable nano-elicitors for inducing immunity in plants. The biodegradable nanoelicitors are developed to induce plant immunity through phytoalexin production in plants e.g. inducing tomato to produce alpha-tomaline against Fusarium wilt of tomato, capsidiol against Chilli anthracnose, sakuranitin against rice blast, Scopletin and anthrocyaidin against Phytophthora or Pythium rot, Durian and scoparone against Phytophthora or Pythium rot of citrus etc. The biodegradable nanoparticles from natural products of active metabolites of Chaetomium spp. are further investigated and discovered as a new scientific investigation, namely microbial degradable nanoelicitors for inducing immunity in plants by the authors. Our research findings have developed to be a natural product of nano-elicitor for plant immunity.

Biological insect is developed by the specific isolates of insect killing fungi, Beauviria bassiana, Metarrhizium anisopliae, Streptomyces avermitis, Isaria sp., Verticillium sp. [40, 41, 42] at concentration of 2 X 106 $\mathrm{CFU} / \mathrm{ml}$. It acts as non-knockdown effect. All stages of insect (eggs, larva, nymphs and molting stages) are gradullay died. Mechanism of control concerns the antifeeding, inhibition the hatching eggs, ungrown the larvae and pupae, or repellent effect of the larvae and adults, and even blocking the molting of larvae and nymphs. This biological insecticide formulation will lead to reduce the adult female and less egg production, disrupt the mating and disturb female to lay eggs. It has formulated as liquid form and recommended to apply is at $50 \mathrm{cc} / 20 \mathrm{~L}$ of water every 7-15 days intervals. The possible target insect pests are cotton bollworm, corn earworm, american bollwarm, leaf hopper, pea pod borer, diamond back moth, boring caterpillar, beet armyworm, cutting armyworm, aphids, thrips, leaf rolling caterpillar, leaf miner, green stink bug, leaf sucking plant louse, and citrus psyllids etc. Natural sulfur either in liquid or powder formulation can be applied to control some insects, thrips and red spider mites etc. It is reported to control powdery mildew, downy mildew and rust. There are several techniques that using to control insects eg, yellow trap, light trap, herb or medicinal plants (neem extracts) [43]. The insects can be protected by using medicinal or herb repellent plants, plant extracts, used light trap, yellow trap, pheromone without toxic chemicals, and natural sulfur etc. The other techniques are cultural practices, maintained soil $\mathrm{pH}$, mulching, organic amendment, mixed cropping system, crop rotation [44].

\subsection{Organic Animal Production}

The organic eggs are demonstrated to produce by treated organic feed to chickens. The preliminary research on finding the appropriate organic animal feed for chickens. The organic forage crop must be planted to serve for animal feed. The research findings are still investigated the potent microorganism for enzymatic microorganism for ruminant animal and for poutry $[45,46]$. The organic markets have been expanded to organic milk, organic beef, organic chicken, organic shrimp and fish etc.

\subsection{Organic Food Processing}

The organic foods are interested by consumers. It concerns the safer farming method and known about the risked in association with conventional agriculture. The consumer demand for organic products has increased to stimulate organic production. Organic products are safe for consumers and more demand in the markets. Organic food is produced by the methods complying with organic standards. The standards vary worldwide. Organic farms concern the cycle resources, ecological balance and biological diversity [47].

\subsection{Organic Certification}

International Federation of Organic Agriculture (IFOAM) is established in 1972 and organic methods become internationally recognized and regulated by many countries and certified organics [48, 49, 50, 51]. Certification for organic agriculture is the production process for organic food both in plants and animal including organic products. Certification can be certified for growers, seed production, and food processing. Organic certification varies from country to country for each regulation in production standard for growing, storage, processing, packaging and shipping. It is included non-agrochemical application, non-genetically organisms(GMO) [2]. The 21st century, there are many countries required organic certification from the growers to realize and confirm as non- 
agrochemical production eg European Union (EU), the United States, Canada, Mexico, and Japan etc. The organic marketing concerns on the label of organic food distribution that is regulated by governmental food safety authorities [52]. The organic food production are normally enforced strictly requirements to check in all steps of the organic production. The organic products that is imported to the EU markets must have a certificate of inspection provided by a control body recognized by the EU.

\subsection{International Federation Of Organic Agriculture Movements Certification (Ifoam)}

International federation of organic agriculture movements (IFOAM) has organized as a non-profit organization leader for organic standards globally since 1980. IFOAM accreditation is internationally adopted by a competency verification to certify organic. IFOAM is established the first organic certification in 1992 [53]. Association of Agricultural Technology in Southeast Asia (AATSEA) is also non-profitable organization which is active in a variety of training programs for organic agriculture and organic certification.

AATSEA has done organically certification in Lao PDR since in August, 6, 2018 and then Vietnam, Cambodia, Myanmar and Thailandn (Figure 2).

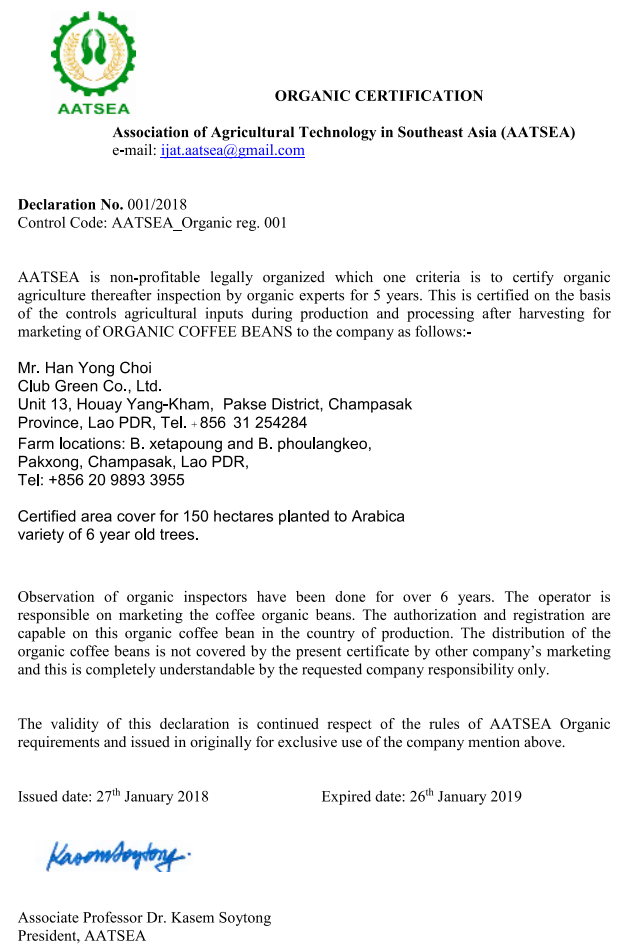

\subsection{Organic Marketing, Extension And Training Program}

The organic market is one of the most important factor for extension and training programs. Organic market will be acceptable level thereafter organic certification from reliable organic certified agents. Organic market in the country is needed to promoted to people about their health. The international organic markets has increasingly demanded. European countries are considered to be the shares of organic food of the markets. Denmark is recorded to be more demand in the highest organic market share (11.5 percent), and is the first country to pass the 10 percent mark, followed by Switzerland (9.9 percent) and Sweden (9.6 percent) in 2018 and others [54]. The marketing research company e.g. Ecovia Intelligence has expected that the organic food market surpassed 100 billion US dollars for the first time in 2018 (almost 97 billion euros). The United States is one of the main organic market with 40.6 billion euros, followed by Germany (10.9 billion euros) and France ( 9.1 billion euros). In 2018, there are many major organic markets have continued to demonstrate a double-digit growth rates, and the French organic market has increased over 15 percent. Danish and Swiss consumers needed the most demand for organic food (312 Euros per capita in 2018). Denmark had concerned the highest organic market share with 11.5 percent of total food market. 2.8 million of organic producers. India becomes the highest number of organic production and followed by Uganda and Ethiopia. Organic agricultural farms are increased at total of 71.5 million in 2018. The growth rate was 2.9 percent or 2 million hectares that compared to 2017. Australia has also become the largest organic agricultural production area (35.7 million hectares), followed by Argentina (3.6 million hectares), and PR China (3.1 million hectares [53]. The organic marketing and certification are the most important key factors for organic product business. The organic products are importantly needed for organic certification by the reliable certified agencies. There are many ways to promote the organic markets eg. contact farms with companies, supermarkets, organic shop, home delivery, and organic restaurants, There are many institutes and agencies have been stimulated and promoted the organic agricultural knowledge by training program. AATSEA has also organized the training programs for organic growers and interesting peoples to gain the based knowledge for commercial scale.

Figure 2. Organic certified by AATSEA 


\section{CONCLUSION}

Future trends for organic agriculture will be needed for increasing motivation of sustainable development goals (SDGs) to reserve our environment and food safety. The organic agriculture model is a proposed practical methodology for non-agrochemical production (NAP) as the first step toward organic agricultural production. We proposes NAP certification as the transition period to be organic certification The proposed model includes the production of organic crop and animal which the related people would have the based knowledge in production, agricultural inputs, organic seeds, organic animal feed, post-harvest technology, food preservation, organic certification, organic markets etc. The certified agricultural inputs for organic agricultural production is needed for successfully production by the growers to meet the quantity and quality of organic products. Research investigation in organic based knowledge must be supported to all related research areas to find out for sustainable development e.g. finding the new bioproducts, organic seed research, animal feed research, food processing, demand and supply in organic research etc. However, AATSEA would like to propose to be a choice for organic certification which the same organic standard as the others. But AATSEA would like to certify non-agrochemical production (NAP) during transition period for organic certification.

\section{ACKNOWLEDGMENTS}

I would like to acknowledge Association of Agricultural Technology in Southeast Asia (AATSEA) for partly supporting to promote organic agriculture in Thailand, China, Myanmar, Vietnam, Laos and Cambodia etc.

\section{REFERENCES}

[1] FAO/WHO, Guidelines for the production, processing, labelling and marketing of organically produced foods, GL 32-1999, Retrieved 2020, from file://C:/Users/Administrator/Downloads/Documen ts/cxg_032e_2.pdf.
[2] A.R. James, E.F. Joyce, International Organic inspection manual, Germany, IFOAM, 2020, ISBN:3934055095.

[3] K. Soytong, S. Kanokmedhakul, V. Kukongviriyapa, M. Isobe, Application of Chaetomium species (Ketomium ${ }^{\circledR}$ ) as a new broad spectrum biological fungicide for plant disease control, A review article. Fungal Diversity, 2001, 7:1-15.

[4] U.S. DEPARTMENT OF AGRICULTURE, Organic 101: Allowed and Prohibited Substances, 2018, Posted by Miles McEvoy, National Organic Program Director in Food and Nutrition Research and Science, Retrieved 2020, from https://www.usda.gov/media/blog/2012/01/25/organic101 allowed-and-prohibited-substances.

[5] S. Kaewchai, K. Soytong, K.D. Hyde, Mycofungicides and fungal biofertilizers, Fungal Diversity, 2009, 38:25-50.

[6] W. Phuwiwat, K. Soytong, The effect of Penicillium notatum on plant growth, Fungal Diversity, 2001, 8:143-148.

[7] H. Tann, C. Makhonpas, A. Utthajadee, K. Soytong, Effect of good agricultural practice and organic methods on rice cultivation under the system of rice intensification in Cambodia, Journal of Agricultural Technology, 2012, 8: 289-303.

[8] P.S. Sibounnavong, A. Utthajadee, C. Makhonpas, K. Soytong, Efficacy test for good agricultural practice, pesticide-free production and organic agriculture in tomato, Journal of Agricultural Technology, 2012, 8:363-376.

[9] C. Hemtasin, S. Kanokmedhakul, P, Moosophon, K. Soytong, K. Kanokmedhakul, Bioactive azaphilones from the fungus Penicillium multicolor CM01, Phytochemistry Letters,2016, 16: 56-60.

[10] B. Chaiyosang, K. Kanokmedhakul, J. Boonmak, S. Youngme, V. Kukongviriyapan, K. Soytong, S. Kanokmedhakul, A new lumazine peptide penilumamide $\mathrm{E}$ from the fungus Aspergillus terreus, Natural Product Research, 2016, 30:9, 1017-1024.

[11] K. Soytong, N.T. Quyet, Production of organic compost from mushroom producing substances waste and tested for Kangkong organic cultivation, Journal of Agricultural Technology, 2013, 9:115123.

[12] J.J. Song, K. Soytong, Research and development on bio-products in China, International Journal of Agricultural Technology, 2018, 14:131-141.

[13] K. Soytong, T.H. Quimio, A taxonomic study on the Philippine species of Chaetomium, The Philippine agriculturist, 1989, 72:59-72. 
[14] N. Panthama, S Kanokmedhakul, K. Kanokmedhakul , K. Soytong, Chemical constituents from the fungus Chaetomium cupreum RY202. Arch, Pharm. Res, DOI, 2014, 10.1007/s12272-014-0418-1.published 10 June 2014. 1-6 p.

[15] J.J. Song, K. Soytong, Chaetomium spp. as biological fertilizer for plant growth, International Journal of Agricultural Technology, 2017, 13:941951.

[16] K. Soytong, Antagonism of Chaetomium cupreum to Pyricularia oryzae, Journal of Plant Protection in the Tropics, 1992a, 9:17-24.

[17] K. Soytong, Biological control of tomato wilt caused by Fusarium oxysporum f.sp. lycopersici using Chaetomium cupreum, Kasetsart Journal (Natural Science), 1992b, 26:310-313.

[18]S. Kanokmedhakul, K. Kanokmedhakul, N. Phonkerd, K. Soytong, P. Kongsaeree, A. Suksamrarn, Anti mycobacterial anthraquinonechromanone compound and diketopiperazine alkaloid from the fungus Chaetomium globosum KMITL- N0802, Planta medica, 2002, 68:834-836.

[19] M. Tveit, M.B. Moore, Isolates of Chaetomium that protect oats from Helminthosporium victoriae, Phytopathology, 1954, 44:686-689

[20] D. Cullen, J.H. Andrews, Evidence for the role of antibiosis in the antagonism of Chaetomium globosum to the apple scab pathogen Venturia inaequalis, Canadian Journal of Botany, 1984, 62:1819-1823.

[21] O.G. Tomilova, M.V. Shternshis, The effect of a preparation from Chaetomium fungi on the growth of phytopathogenic fungi, Applied Biochemistry and Microbiology, 2006, 42:76-80.

[22] M. Shternshis, O. Tomilova, T. Shpatova, K. Soytong, Evaluation of Ketomiummycofungicide on Siberian isolates of phytopathogenic fungi, Journal of Agricultural Technology, 2005, 1:247-253.

[23] S. Prechaprome, K. Soytong, Integrated biological control of durian stem and root rot caused by Phytophthora palmivora, Proceedings of the First International Symposium on Biopesticides, Thailand, October 27-31, 1997, 228-237.

[24] P. Usuwan, K. Soytong, Biological control of Phytophthora rot of citrus in the th field, Proceedings of the First International Symposium on Biopesticides, Thailand, October 27-31, 1998.

[25] P. Sodsa-art, K. Soytong, Biological control of black pepper root and basal stem rot in the field. Proc. os Symposium on Biological Control in
Tropics, MARDI Training Centre, 18-19 Malaysia 1999, 68-70 pp.

[26] K. Soytong, P. Usuwan, S. Kanokmedhakul, K. Kanokmedhakul, V. Kukongviriyapan, M. Isobe, Integrated biological control of Phytophthora rot of sweet orange using mycofungicides in Thailand, Proceedings of the 5th International Conference on Plant Protection in the Tropics, 1999, March 15-18. Malaysia. 329-331 pp.

[27] J.K. Nitao, S.L.F. Meyer, J.E. Oliver, W.F. Schmidt, D.J. Chitwood, Isolation of avipin, a fungus compound antagonistic to plant-parasitic nematodes, Nematology, 2002, 4:55-63.

[28] W. Zhou, J.L. Starr, J.L. Krumm, G.A. Sword, The fungal endophyte Chaetomium globosum negatively affects both above- and belowground herbivores in cotton. FEMS Microbiology Ecology, 2016 Volume 92, Issue10, fiw158, https://doi.org/10.1093/femsec/fiw158.

[29] R. Kooliyattil, L.M. Dandua, G.R. Knudsen, Prospecting fungal parasites of the potato cyst nematode Globodera pallida using a rapid screening technique, Journal of Basic Microbiology, 2017, 57:386-392.

[30] B. Khan, W. Yan, S. Wei, Z.Y. Wang, S.S. Zhao, L.L. Cao, N.A. Rajput, Y. Ye, Nematicidal metabolites from endophytic fungus Chaetomium globosum YSC5, 2019, DOI: 10.1093/femsle/fnz169.

[31] A.L. Abdel, Chaetominedione, a new tyrosin kinase inhibitor isolated from the algicolous marine fungus Chaetomium sp., Tetrahedron Letters, 2008, 49:6398-6400.

[32] J.H. Park, G.J. Choi, K.S. Jang, H.K. Lim, H.T. Kim, K.Y. Cho, K. Y. J.C. Kim, Antifungal activity against plant pathogenic fungi of chaetoviridins isolated from Chaetomium globosum, FEMS Microbiology Letters, 2005, 252:309-313.

[33] S. Kanokmedhakul, K. Kanokmedhakul, P. Nasomjai, S. Loungsysouphanh, K. Soytong, M. Isobe, P. Kongsaeree, S. Prabpai, S. A. Suksamrarn, Antifungal azaphilones from the fungus, Chaetomium cupreum CC3003, Journal of Natural Products, 2006, 69:891-895.

[34] O.H. Elibol, D.D. Morisette, J.P. Denton, R. Bashir, Integrated nanoscale silicon sensors using topdown fabrication, Applied Physics Letters, 2003, 83:4613-4615.

[35] O.V. Salata, Application of nanoparticles in biology and medicine. Journal of Nano- biotechnology, 2004, 2: 3. 
[36] W. Li, X. Yang, Y. Yang, R. Duang, G. Chen, X. Li, Q. Li, S. Qin, S. Li, L. Zhao, Z. Ding, Antiphytopathogen, multi-target acetylcholinesterase inhibitory and antioxidant activities of metabolites from endophytic Chaetomium globosum, Natural Product Research, 2016, 30:2616-2619.

[37] W. Soutter, Nanotechnology in agriculture, AZoNano.com Publishers, 2013, Available at http://

www.azonano.com/article.aspx?ArticleID=3141 \#1\%20.

[38]J.J. Song, Soytong, K., Kanokmedhakul, S., Kanokmedhakul, $\mathrm{K}$ and Poeaim, Antifungal activity of microbial nanoparticles derived from Chaetomium spp against Magnaporthe oryzae causing rice blast, Plant Protection Science, 2020a, 56, 2020 (3): 1-11.

[39] J.J. Song, K. Soytong, S. Kanokmedhakul, K. Kanokmedhakul, K. Poeaim, Natural Product of Nano-particles constructed from Chaetomium spp to control rice blast disease caused by Magnaporthe oryzae, International Journal of Agriculture \& Biology, 2020b 23:1013-1020.

[40] O.M. Aung, K. Soytong, K.D. Hyde, Diversity of entomopathogenic fungi in rainforests of Chiang Mai Province, Thailand. Fungal Diversity, 2008, 30:15-22.

[41] O.M. Aung, J.C. Kang, Z.Q. Liang, K. Soytong, K.D. Hyde, Cordyceps nrciensis sp. Nov from a spider in Thailand, Mycotaxon, 2006a, 97:235240.

[42] O.M. Aung, J.C. Kang, Z.Q. Liang, K. Soytong, K.D. Hyde, A new entomopathogenic species, Hymenostilbe furcata, parasitic on a hemiptera nymph in northern Thailand, Mycotaxon, 2006b, 97:235-240.

[43] B.E. Sambo, P.C. Okutu, Effects of neem extract on insect pest complex of grapevine (Vitis vinifera L.), International Journal of Organic Agriculture Research and Development, 2010, 1:53-65.

[44] T.I. Olabiyi, P.J.C. Harris, J.J. Atungwu, A. Rosenfeld, Assessment of crop rotation and soil fertility building schemes in selected organic farms in England, International Journal of Organic Agriculture Research and Development, 2010, $1: 38-51$.
[45] W. Suphalucksana, K. Soytong, Significance of Chaetomium cupreum for ruminant nutrition improvement through biodegradation, International Journal of Agricultural Technology, 2006, 2:155163.

[46] W. Suphalucksana, K. Soytong, Lactic acid bacteria and enzyme production in silage of guinea grass (Panicum maximum), Bulgarian Journal of Agricultural Science, 2017, 23:86-91.

[47] FiBL and IFOAM - Organics International, The World of Organic Agriculture Statistics and Emerging Trends 2019, Retrieved 2020, from https://ciaorganico.net/documypublic/486_2020organic-world-2019.pdf.

[48] D.H. Stinner, The science of organic farming. In: William Lockeretz. Organic farming: An International History. Oxfordshire, UK \& Cambridge, Massachusetts: CAB International (CABI), 2007, ISBN 978-1-84593-289-3, Retrieved 30 April 2013.

[49] P.A. Horne, Integrated pest management for crops and pastures, CSIRO Publishing, 2008, p. 2.

[50] J. Paull, From France to the world: The International Federation of Organic Agriculture Movements (IFOAM), Journal of Social Research and Policy, 2010, 1:93-102.

[51] M. Gold, What is organic production. National Agricultural Library. USDA. Retrieved 1 March 2014.

[52] Organic certification, European Commission: Agriculture and Rural Development, Organic certification has been performed by Organic USDA, 2014, Retrieved 2020, from https://www.ams.usda.gov/services/organiccertification.

[53] IFOAM - Organics International, Global Organic Area Continues to Grow, 2020, Retrieved 2020, from https://www.ifoam.bio/global-organic-areacontinues-grow.

[54] BIOECOACTUAL, Organic market worldwide: observed trends in the last few years, 2020, Retrieved 2020, from https://www.bioecoactual.com/en/2020/03/10/organicmarket-worldwide-observed-trends-in-the-last-fewyears/. 